\title{
Grief \& Personal Growth: Reflection from Quran, Hadith and Modern Medicine
}

\author{
Nor Jannah Nasution Raduan ${ }^{1}$, Najwa Hanim Mat Rosly ${ }^{2}$, Zul Azlin Razali ${ }^{3}$, Muhammad Al Siddiq ${ }^{4}$, Mohd Razali \\ Salleh ${ }^{1}$ \\ ${ }^{1}$ Department of Psychiatry, Faculty of Medicine, Universiti Teknologi MARA. \\ ${ }^{2}$ Department of Psychiatry, Kuliyyah of Medicine, International Islamic University Malaysia,Kuantan \\ ${ }^{3}$ Faculty of Medicine and Health Science, Universiti Sains Islam Malaysia. \\ ${ }^{4}$ Faculty of Hadith and Islamic Studies, University of Madinah
}

\begin{abstract}
Grief has been defined as the reaction towards loss with typical symptoms including sadness, anger, guilt, yearning, regret, loneliness, numbness and positive feelings related to individual's personal experience. Grief has been postulated to occur when a safe and secure bond has been threatened. This loss can be an opportunity for personal growth. It is growth that emerges from difficult life events. It may occur during or after the process of grieving. We reviewed three cases related to grief and personal growth. Three cases were described where grief and personal growth were observed. Each case occurred in different situations. These different situations were; an adult child and caregiver of patient with dementia, a widow who loss her husband from drowning, and a cancer survivor who experienced psychological and spiritual growth from the loss and adverse life event. As a comparison three stories taken from the Quran and Hadith were analyzed to reflect on the three case discussions. The Quran and Hadith have mentioned stories of personal growth emerging from difficulties. The completeness of Islamic creed has never neglected the spiritual component in treating medical, physical and psychological illnesses. Islamic spirituality facilitates and enhances personal growth in the aftermath of any physical and psychological tribulations. It is important to merge the spiritual aspects of grief from Islamic perspective, as to aid those suffering from grief to attain personal and spiritual growth.
\end{abstract}

KEYWORDS: bereavement, spiritual growth, psychospirituality.

\section{INTRODUCTION}

\section{Does Grief lead to Growth?}

Recently over the years, many western scholars have discussed depth the dimensions of grief and personal growth. ${ }^{1,2}$ It is important to have a paradigm shift towards the impact of grief to one's personal experience of growth.

Grief has been defined as a psychological response, which includes components of emotional, cognitive, functional and behavioural responses to a loss such as death. ${ }^{1}$ Grief can also be used to refer to the response to other kinds of loss; people grieve the loss of their youth, missed opportunities, and functional abilities. Mourning is also interchangeably used with grief, usually referring more specifically to the behavioural manifestations of grief, which are influenced by social and cultural rituals, such as funerals or other customs. ${ }^{2}$

Corresponding author:

Nor Jannah Nasution Raduan

Department of Psychiatry,

Faculty of Medicine,

Universiti Teknologi MARA,

47000 JIn Hospital, Sungai Buloh

Selangor, MALAYSIA

Email:jannahraduan@gmail.com, norjannah@salam.uitm.edu.my
Grief can present with typical symptoms including sadness, anger, guilt, yearning, regret, loneliness, numbness and positive feelings related to individual's personal experience. Grieving process has been postulated to have led to growth experiences in some individuals. ${ }^{3}$ According to Ryff (1989), personal growth is a component of psychological well-being that involves feelings of continued development, seeing oneself as growing and expanding, being open to new experiences, seeing improvement in self and behavior over time, and being able to change in ways that reflect more selfknowledge and effectiveness. ${ }^{3}$

Several literatures have focused on this concept and identify growth outcomes from grief, such as personal and spiritual development with and increased coping skills. ${ }^{4}$ These developments also lead to an enhanced personal resources and relationships and leading to changes in religious and spiritual assumptions, beliefs and attitudes that help produced a transformation in the psychospiritual aspects. ${ }^{5-7}$ Spirituality, social support, and stressors were found to have a positive relationship to personal growth. Therefore the more stressful an event experienced by an individual, the more growth one may experience. ${ }^{8}$

Spirituality in the process of navigating grief

The experience of personal growth in the domain 
of spirituality can occur in grieving individuals irrespective of spiritual or religious beliefs. ${ }^{9}$ Psycho -spiritual transformation and growth from adversity are also known as spiritual emergence. ${ }^{10,11}$ A highly stressful event or adversity may trigger spiritual emergence. According to Bonanno (12), reactions to grief are designed to help individuals 'accept and accommodate losses relatively quickly so that we can continue to live productive lives'.

Spiritual emergence occurs by acceptance or readiness to integrate transpersonal, religious and spiritual experiences resulting in maturity and expansion of consciousness. It allows individuals to make changes to values and existential priorities that lead to expanded worldview, improved health, greater interest in living and personal satisfactions, and an openness to religious and spiritual experiences. ${ }^{13}$ Hence psycho-spiritual transformation is experienced as a unique event as it leaves the person who had suffered from loss, a momentous change to appreciate and acknowledge self, life and people better. These include appreciating trivial things in life and building stronger connection with the Creator through having good assumptions to the Creator. ${ }^{13}$

Spirituality is a vital component in management of grief. It is seen in two diverse ways in psychospiritual transformation. First, spirituality occurs subtly and remains silent until adversity strikes. Secondly, spirituality is seen as being supportive through finding a deeper meaning to self, to others and the transcendent. ${ }^{13}$

Experience of growth is directly attributed to stressful life events, and according to Tedeschi and Calhoun $^{14}$; the kinds of growth experiences as described by those people going through grief, falls into five broad categories namely the experience of the emergence of new possibilities, changes in relationships with others, an increased sense of personal strength, a greater appreciation for life, and changes in existential and spiritual orientations.

In 2011, more than 500 papers and studies have been written about the positive association between religiosity or spirituality and better mental health and well-being. ${ }^{15}$ Hope, which is equated with optimism, is a key component of Muslim thinking as characterized by basic teaching of Islam. Tremendous rewards await the believers who are sincere in their supplications. The whole of Quran is a cure for corruption of knowledge and corruption of intent, which in turn leads to many illnesses stemmed from anger and misguidance. ${ }^{16}$

Tests and tribulations are closely associated with faith (eeman) as Allah has said in the Quran; "Do people think that they will be left alone because they say: "We believe," and will not be tested. And We indeed tested those who were before them so that Allah will indeed know those who are true, and He will know those who are liars". ${ }^{17}$ The tests come in many forms and one of them could be the loss of something or loved ones; "And certainly, We shall test you with something of fear, hunger, loss of wealth, lives and fruits, but give glad tidings to AsSabirin (the patient)". ${ }^{18}$

\section{Reflection of Case Series and Stories of Quran and Hadith}

Three cases of grief and personal growth are discussed and three related stories from the Quran and Hadith to reflect on the lessons and the associations. These cases include an adult child and caregiver of patient with dementia, a widow who loss her husband from drowning and a cancer survivor, positive outcome was experienced as personal growth.

\section{Case 1}

Mr. A, a 30 year old man, single, sales manager, presented with 8 years history of multiple substance addiction; stimulant, hallucinogen and cannabis. He was fighting with his addiction for many years to no avail. Upon the final years of his addiction, his mother was diagnosed with fronto-temporal dementia. His mother was his strongest support in fighting the addiction battle; thus the illness of his mother became a devastating event and instant loss of support. He was battling with addiction whilst taking care of his mother as she was going through many challenging behavioural changes.

As his mother's condition worsen, he developed pathological grieving towards his mother's loss of personality, memory, speech and language. Over time, he took full responsibility in taking care of his mother, as she was not able to care for herself. During sessions with the therapist, he shared his evolving personal experiences from grieving through the progressive deterioration of his mother's cognitive and physical function, to taking over the responsibility as primary caregiver of his mother. The many years of caregiving have healed him as he goes through a lot of self-reflection and sacrifices.

Through self-reflection, he felt a strong spiritual emergence of connection with God and having good assumptions (husnu zahn) towards God, self and others. These experiences became a strong basis in rebuilding a new meaning in his life to redeem his past. As he was able to appreciate life better and found meaning in his life, he was able to completely stop his addiction and continued caregiving for his mother. He felt his sacrifices for his mother led to the experience of growth; namely seeing himself as being open to new experiences, seeing improvement in himself and behaviour over time, and being able to change in ways that reflect more self-knowledge and effectiveness.

"Umar b. Khattab reported: I heard Allah's Messenger ( ) as saying: Worthy amongst the successors would be a person who would be called Uwais. He would have his mother (living with him) and he would have (a small) sign of leprosy. Ask him to beg pardon for you (from Allah), ". ${ }^{19}$ 
Usair b. Jabir reported that when people from Yemen came to help (the Muslim army at the time of jihad) he asked them: Is there amongst you Uwais b. 'Amir? (He continued finding him out) until he met Uwais. He said: Are you Uwais b., Amir? He said: Yes. He said: Are you from the tribe of Qaran? He said: Yes. He (Hadrat) 'Umar (again) said: Did you suffer from leprosy and then you were cured from it but for the space of a dirham? He said: Yes. He ('Umar) said: Is your mother (living)? He said: Yes. He ('Umar) said: I heard Allah's Messenger ( ) say: There would come to you Uwais b. Amir with the reinforcement from the people of Yemen. (He would be) from Qaran, (the branch) of Murid. He had been suffering from leprosy from which he was cured but for a spot of a dirham. His treatment with his mother would have been excellent. If he were to take an oath in the name of Allah, He would honour that. And if it is possible for you, then do ask him to beg forgiveness for you (from your Lord). So he (Uwais) begged forgiveness for him. Umar said: Where do you intend to go? He said: To Kufa. He ('Umar) said: Let me write a letter for you to its governor, whereupon he (Uwais) said: I love to live amongst the poor people. When it was the next year, a person from among the elite (of Kufa) performed Hajj and he met Umar. He asked him about Uwais. He said: I left him in a state with meagre means of sustenance. (Thereupon) Umar said: I heard Allah's Messenger ( )as saying: There would come to you Uwais $b$. 'Amir, of Qaran, a branch (of the tribe) of Murid, along with the reinforcement of the people of Yemen. He had been suffering from leprosy, which would have been cured, but for the space of a dirham. His treatment with his mother would have been very kind. If he would take an oath in the name of Allah (for something) He would honour it. Ask him to beg forgiveness for you (from Allah) in case it is possible for you. So he came to Uwais and said.: Beg forgiveness (from Allah) for me. He (Uwais) said: You have just come from a sacred journey (Hajj) ; you, therefore, ask forgiveness for me. He (the person who had performed Hajj) said: Ask forgiveness for me (from Allah). He (Uwais again) said: You have just come from the sacred journey, so you ask forgiveness for me. (Uwais further) said: Did you meet Umar? He said: Yes. He (Uwais) then begged forgiveness for him (from Allah). So the people came to know about (the status of religious piety) of Uwais. He went away (from that place). Usair said: His clothing consisted of a mantle, and whosoever saw him said: From where did Uwais get this mantle?". ${ }^{20}$

The story of Uwais reminds us of the case of Mr. A, who struggled and sacrificed himself to care for his ill mother. His sacrifice had successfully saved him from his multiple substance addictions. He grows personally by being a responsible son; and spiritually by having a clearer and deeper insight of Allah the Magnificent. Prayers, hope and faith in Allah the Almighty helped him managed his difficult times and troubled feelings. As Uwais was promised paradise,
Mr. A could be heading in the similar path too, by the will of Allah.

Case 2

Mrs. E, a 35 years old housewife with 4 children, loss her husband due to drowning. She was devastated and seek therapy for her grief. While hopelessly struggling with the grief in the beginning, she had strong support from her family. As she went through the emotional pain, she experienced strengthening in her spirituality. She started to learn and understand Islam, started performing solah (prayers) and supplicating frequently to Allah the Exalted. Through this reconnection with spirituality, she felt she had much stronger support from something larger than life, a supreme being that is Allah the Exalted. It has bolstered her confidence and determination. It has made her interpersonal relationship with others better. She understood the purpose and meaning in life through acceptance of her husband's death.

Losing a loved one is never easy, especially if it was the significant other. Umm Salama reported Allah's Messenger ( ) as saying: If any Muslim who suffers some calamity says, what Allah has commanded him," We belong to Allah and to Him shall we return; $O$ Allah, reward me for my affliction and give me something better than it in exchange for it," Allah will give him something better than it in exchange. When Abu Salama died she said: What Muslim is better than Abu Salama whose family was the first to emigrate to the Messenger of Allah ( ) then said the words, and Allah gave me God's Messenger ( )in exchange. She said: The Messenger of Allah ( ) sent Hatib b. Abu Balta'a to deliver me the message of marriage with him. I said to him: I have a daughter (as my dependant) and I am of jealous temperament. He (the Holy Prophet) said: So far as her daughter is concerned, we would supplicate Allah, that He may free her (of her responsibility) and I would also supplicate Allah to do away with (her) jealous (temperament),". ${ }^{21}$

History has told us of how difficult it was for Ummu Salamah to accept the death of her husband, the man she loved dearly and longed to meet him in Paradise. Due to her piety and faith in Allah the Exalted, she kept supplicating and putting her faith and hope in Allah the Almighty. Beyond her imagination, Ummu Salamah was then given a man whom she would have never imagined to marry; it was the Prophet (w). This experience made her appreciate the significance of supplication to Allah the Exalted and being thankful and thinking good of Allah the Almighty. This story is evidence to all mankind to put hope and trust in Allah that recovery is possible in any way as long as good assumptions to Allah the Exalted is worked for.

It is important to understand that in difficult times, coping with hope and trust in Allah the Exalted build a multitude of growth in oneself. The spiritual and religious growth as seen in Mrs. E, was unimaginable 
but it successfully made her stronger and bounced back with much resilience to care for herself and her four children, all of whom were in need of emotional, spiritual and physical care and support.

\section{Case 3}

Ms. N, a 30 years old single lady, a professional with a promising career and future, was diagnosed with breast cancer after presented with 3 months history of painless breast lump. Subsequently she had to take long leave to manage her condition and go through various treatments. She was shocked initially and was in denial about treatment. She was not able to accept at a very young age she had to go through mastectomy of the right breast and chemotherapy but Eventually after therapy and counselling sessions she was able to move ahead to accept the illness she had had. However there were times when she would have insomnia with recollection of the adverse effects from her chemotherapy leading to crying spells and anxiety. She would have bouts of feeling low with hopelessness and worthlessness.

After her treatment was completed and cancer free, she started to volunteer for those in need. She postponed her career plans and gave special attention and time for the homeless sick, poor and also cancer patients. A lot of sacrifices in energy, time and money were given to those in need. At the time when she felt no control over everything especially her health, she found spiritual emergence through the connection with her spirituality. She felt profound awareness in herself of the real meaning and purpose in life. It is to appreciate whatever she had left and to let go of the possessiveness of this world be it material, career or her own body. Through these self-reflections, she felt easier to reconstruct and rebuild good assumptions on the Creator, herself and the world. The grief did not end, she loss part of her body through mastectomy, but she was able to accept and continue to experience significant growth and change throughout her life.

Important lessons learnt from Prophet Ayyub (a.s.) through his patience, steadfastness and forbearance in all the tests sent to him by the will of Allah the Exalted. Prophet Ayyub (a.s.) was tested through his wealth, family and health. He remained steadfast through his loss and never once was he ungrateful towards the entire blessing that Allah the Exalted has given him prior to his illness. Iblis tried his best to defeat Ayyub (a.s.) patience and steadfastness but throughout his painful illness, Prophet Ayyub (a.s.) was forbearing and never give in to the lies and deceptions of Iblis. Prophet Ayyub (a.s.) supplication was told to us in the Quran; "And (remember) Ayyub (Job), when he cried to his Lord: 'Verily, distress has seized me, and You are the Most Merciful of all those who show mercy,". ${ }^{22}$

Pondering on stories of Prophet Ayyub (a.s.) revealed the power of maintaining good assumptions to oneself and the Creator, Allah the Exalted.
Stressful life events provide great opportunities for transformation of an individual's relationship with their spirituality and religion. It provides buffer towards pathological grief or depressive episode. It will in turn shape the entire experience of grief. ${ }^{12}$ Being tested in health reminds us of Ms. $\mathrm{N}$ who almost loss her health and her life. For her, getting well is as if getting the autonomy on her health again. It strongly helped her to rebuild and reconstruct her view on life. Her experiences of growth were felt through cognitive maturity and in her psychological and personal strength; and spiritual and religious development. As she found meaning in her life and personal strength through her adversity, she felt the need to devote her by helping others through adversity.

\section{DISCUSSION}

\section{Reflections in grief work}

It is important to understand the importance of reflection in people who are grieving. It is important for clinicians to understand the usefulness of reflection in grief work. Individuals who are subjected to intrusions of thoughts from grieving with profound religious and spiritual content are urged to examine them and make meaning through narrative or storytelling and incorporate them into their worldview.

Grief is a distressing condition. Human tend to remember God the most during distressing situations. Spiritual reflection during grief may bring one to the remembrance of Allah s.w.t. It makes the individual closer to his Creator through dhikir and supplication to his Rabb. As Allah mentioned in Surah al-Ra'd, "Verily in the remembrance of Allah do hearts find rest" . ${ }^{23}$ Hence dhikir becomes a very important tool in bringing peace and calmness during distress. Every person who supplicate in a state that combines hope and fear, hopes for Allah's mercy and fear of His punishment. Amazingly, it leads to humbleness and submissiveness only to Allah the Al-Mighty. These are among the qualities of one grows into while experiencing grief.

Literature tells us that spiritual development in grieving process may depend on the willingness of others to discuss religious or spiritual issues. Others may include support groups, relatives, friends or even therapists. Although there are individual differences, most grieving persons want to talk about their situation with others. ${ }^{14}$ According to Dyregrov $^{24}$ individuals who are able to share their stories without constraint, receive supportive responses from others and are able to receive social guide on how to cope in a positive spiritual manner therefore may be more likely to emerge from the grief with a more satisfactory spiritual life.

Spirituality is multidimensional. It is however, a very important approach in those who are grieving as it brings strength and hope in despair. The personal experience during grieving process may emerge through many possibilities of growth if more 
emphasis on positive spiritual coping is given, especially in spiritually inclined patients. It should also be remembered that psycho-spiritual transformation is a process and it is based on individual basis. Among other qualities of spiritual growth in adversity is patience (sabr). It is always reminded in the Quran the importance of sabr. Allah s.w.t mentioned in the Quran, "Be patient and persevere, for Allah is with those who patiently persevere". ${ }^{25}$ Allah the Al-Mighty commanded His Messenger to endure with patience in carrying His commands and reminded the Prophet" (跣), Be steadfast, your steadfastness is only from Allah. Do not grieve over them; do not be distressed by their scheming. Surely Allah is with those who are mindful and do good". ${ }^{26}$ Spiritual growth makes one understand that triumph is joined with endurance, relief with distress and ease with hardship.

In medical perspectives, grief is seen as a complex process. As much as it causes psychological and emotional pain from the loss and negative emotions, one can also benefit from the opportunity to grow. The Quran and Hadith have given examples of those who have grieved and successfully attained the benefit of it in this world. As mentioned in a Hadith, Narrated Abu Sa' id Al-Khudri and Abu Huraira: The Prophet ( ) said , "No fatigue, nor disease, nor sorrow, nor sadness, nor hurt, nor distress befalls a Muslim, even if it were the prick he receives from a thorn, but that Allah expiates some of his sins for that." ${ }^{27}$ Hence this opportunity for personal growth through grief should be given adequate reflection and importance to build a new meaningful life in this world and in the hereafter. As being reminded in a Hadith, Suhaib reported that Allah's Messenger ( ) said: Strange are the ways of a believer for there is good in every affair of his and this is not the case with anyone else except in the case of a believer for if he has an occasion to feel delight, he thanks (God), thus there is a good for him in it, and if he gets into trouble and shows resignation (and endures it patiently), there is a good for him in $i t, " .{ }^{28}$

Those who are in distressed such as grieving or depression has a higher advantage if these conditions make them in remembrance of Allah. As we are reminded by a Hadith Qudsi, Abu Huraira reported Allah's Messenger ( ) as saying that Allah, the Exalted and Glorious, thus stated: I am near to the thought of My servant as he thinks about Me, and I am with him as he remembers Me. And if he remembers Me in his heart, I also remember him in My Heart, and if he remembers Me in assembly I remember him in assembly, better than his (remembrance), and if he draws near Me by the span of a palm, I draw near him by the cubit, and if he draws near Me by the cubit I draw near him by the space (covered by) two hands. And if he walks towards Me, I rush towards him,". ${ }^{29}$

The relationship of a religious person to God is one of dependency. Unfortunately, modern psychiatry is largely influenced from the start by the psychoanalytic school pioneered by Sigmund Freud. To refute Freud's opinion that believing in God and depending on Him is 'infantile and regressive', one should note that maturity is not the opposite of dependency. All human being need perpetual interdependent relationship that is complementary and reciprocal. ${ }^{30}$ Believing in the only One, Allpowerful and All-encompassing Creator and Sustainer of the universe with His appropriate attributes such as All-Knowledgeable, Most Compassionate and AllControlling, would definitely relieve human being from their misery and confusions. The purification of heart or tazkiyatunnafs, which is done properly without innovations or bid'ah, is superior to any form of modern psychological technique. ${ }^{15}$

\section{CONCLUSION}

Spiritual coping has a special place in the creed ('aqeedah) of Islam. Besides the emphasis to use the 'aql (science) to facilitate our worldly life, Islam teaches us on how to cope spiritually with appropriate rituals. Muslims are encouraged to seek help from the logical and rational point of view such as seeking professional help for depression and grief, and at the same time are instructed to strengthen the connection with Allah. The purification and the cleansing of one's soul and spiritual realms are vital process to achieve both physical and mental well-being. The rituals of remembering Allah (dhikir) which is based on authentic divine sources should be incorporated in the treatment and in the process of recovery of any form of ailments. Islamic psycho-spiritual therapy should involve spiritual aspects as well as any techniques that is based on sound knowledge and evidence regardless of the sources if it does not run counter to the tawheed (the concept of Oneness of Allah) and the Islamic law.

\section{REFERENCES}

1. Prigerson HG, Maciejewski PK. Grief and acceptance as opposite sides of the same coin: setting a research agenda to study peaceful acceptance of loss. The British Journal of Psychiatry. 2008 Dec;193(6):435-7.

2. Zisook S, Shear K. Grief and bereavement: what psychiatrists need to know. World Psychiatry. 2009 Jun;8(2):67-74.

3. Ryff CD. Happiness is everything, or is it? Explorations on the meaning of psychological well-being. Journal of personality and social psychology. 1989 Dec;57(6):1069.

4. Schaefer JA, Moos RH. Bereavement experiences and personal growth. 2001.

5. A. Gamino, Kenneth W. Sewell, Larry W. Easterling L. Scott and White grief study-Phase 2: Toward an adaptive model of grief. Death Studies. 2000 Oct 1;24(7):633-60.

6. Balk DE. Bereavement and spiritual change. Death Studies. 1999 1;23(6):485-93. 
7. Marrone R. Dying, mourning, and spirituality: A psychological perspective. Death studies. 1999 Aug 1;23(6):495-519.

8. Cadell S, Regehr C, Hemsworth D. Factors contributing to posttraumatic growth: A proposed structural equation model. American Journal of Orthopsychiatry. 2003 Jul;73(3):27987.

9. Tedeschi RG, Calhoun LG. Beyond the concept of recovery: Growth and the experience of loss. Death studies. 2007 Dec 25;32(1):27-39.

10. Grof S, Grof C, editors. Spiritual emergency: When personal transformation becomes a crisis. TarcherPerigee; 1989.

11. Grof C, Grof S. The stormy search for the self: a guide to personal growth through transformational crisis. Los Angeles: Jeremy P. Tarcher. Inc; 1990.

12. Bonanno GA. The other side of sadness: What the new science of bereavement tells us about life after loss: Basic Books; 2009 Sep 22.

13. Lancaster BL, Palframan JT. Coping with major life events: The role of spirituality and selftransformation. Mental Health, Religion and Culture. 2009 Apr 1;12(3):257-76.

14. Tedeschi RG, Calhoun LG. Time of change? The spiritual challenges of bereavement and loss. OMEGA-Journal of Death and Dying. 2006 Aug;53(1):105-16.

15. Utz A. Psychology from the Islamic perspective. Riyadh, Saudi Arabia: International Islamic publishing house; 2011.

16. Al-Jauziya IIQ. Healing with the Medicine of the Prophet (PBUH): Darussalam Publishers; 1999.

17. Qur'an 29:2-3

18. Qur'an 2:155

19. Muslim. Sahih 44:320 [Internet]. [cited 19 July 2018]. Available from https://sunnah.com/muslim/44/320.

20. Muslim. Sahih 44:321 [Internet]. [cited 19 July 2018]. Available from https://sunnah.com/muslim/44/321.

21. Muslim. Sahih 11:4 [Internet]. [cited 19 July 2018]. Available from https://sunnah.com/muslim/11/4.

22. Qur'an 21:83

23. Qur'an 13:28

24. Dyregrov K. Micro-sociological analysis of social support following traumatic bereavement: Unhelpful and avoidant responses from the community. Omega-Journal of Death and Dying. 2004;48(1):23-44.

25. Qur'an 8:46

26. Qur'an 16:127-128

27. Bukhari. Sahih 75:2 [Internet]. [cited 19 July 2018]. Available from https: //sunnah.com/muslim/75/2

28. Muslim. Sahih 55:82 [Internet]. [cited 19 July 2018]. Available from https://sunnah.com/muslim/55/82

29. Muslim. Sahih 48:1 [Internet]. [cited 19 July 2018]. Available from https: / / sunnah.com/muslim/48/1

30. Van Praag HM. God's champions and adversaries: About the borders between normal and abnormal religiosity. Religion and Psychiatry: Beyond Boundaries. 2009:235-51. 